\title{
Oxidative Degradation of Methyl Green Dye by Cyanide Ion in Aqueous Perchloric Acid Medium; Kinetics, Thermodynamic and Mechanistic Approach.
}

\author{
Sulaiman B. A ${ }^{1}$, Osunlaja, A. A ${ }^{2}$, Mallam W. J, ${ }^{3}$ Ndahi N. ${ }^{1}$ and Mindia A. A ${ }^{1}$ \\ ${ }^{1}$ Department of Chemistry, University of Maiduguri, Borno State, Nigeria \\ ${ }^{2}$ Department of Chemistry, Federal University Gashua, Yobe State, Nigeria \\ ${ }^{3}$ National Research Institute for Chemical Technology (NARICT) Kano State, Nigeria
}

[*Email: abuphauxan@gmail.com, Tel: +2348038565387]

DOI: $10.31364 / \mathrm{SCIRJ} / \mathrm{v} 7 . i 8.2019 . P 0819683$

http://dx.doi.org/10.31364/SCIRJ/v7.i8.2019.P0819683

\section{Abstract}

The Kinetics of the redox reaction of methyl green $\left(\mathrm{MG}^{2+}\right)$ and Cyanide ion $\left(\mathrm{CN}^{-}\right)$in aqueous $\mathrm{HClO}_{4}$ has been investigated spectrophotometrically at $\left[\mathrm{H}^{+}\right]=2.0 \times 10^{-3} \mathrm{~mol} / \mathrm{dm}^{3}, \mu=0.196 \mathrm{~mol} / \mathrm{dm}^{3}, \mathrm{~T}=31 \pm 1^{\circ} \mathrm{C}$ and $\lambda_{\max }=630 \mathrm{~nm}$. The reaction is first order in (oxidant: reductant). With second order overall, with stoichiometry of 1:2 (Oxidant:Reductant). The observed rate constants were not affected by changes in acid concentration, but enhanced by change in ionic strength concentration. The rate constant was catalyzed mildly with varying dielectric constant of the reaction medium. Added anions have no effect the reaction while cations inhibit the reaction rate. The reaction obeys the rate law:

$$
\begin{gathered}
-\frac{d\left[M G^{2+}\right]}{d t}=\mathrm{k}_{2}\left[\mathrm{MG}^{2+}\right]\left[\mathrm{CN}^{-}\right] \\
\mathrm{k}_{2}=(4.00 \pm 0.06) \times 10^{-1} \mathrm{dm}^{3} / \mathrm{mol} / \mathrm{s}
\end{gathered}
$$

Evidence from Spectroscopic study suggests the absence of stable intermediate complexes at the course of the reaction. Also, the activation enthalpy $\left(\Delta \mathrm{H}^{*}=+24.942 \mathrm{~kJ} / \mathrm{K} / \mathrm{mol}\right)$ and entropy $\left(\Delta \mathrm{S}^{*}=-0.173 \mathrm{KJ} / \mathrm{K} / \mathrm{mol}\right)$ were determined in favour of endothermic reaction. Plausible mechanism involving an outer-sphere complex has been proposed to explain the results.

Keywords: Kinetics; Mechanism; Outer-sphere; Methyl green; Thermodynamic; Activation Parameter.

\section{INTRODUCTION}

Methyl green, ([4-[4-dimethyl aminophenyl) -4-dimethylazaniumylidene cyclohexa-2,5-1-ylidene)methyl)phenyl]trimethylazanium dichloride) is a basic triphenylmethane-type dicationic dye which is green in colour, with wavelength of maximum absorption $\lambda_{\max }$ of $630 \mathrm{~nm}$, molecular formular $\mathrm{C}_{26} \mathrm{H}_{33} \mathrm{C}_{12} \mathrm{~N}_{5}$ and formular weight of $458.7 \mathrm{gmol}^{-1}{ }^{-1}$ [1]. It is usually used for staining solutions in medicine and biology and as a photochromophore to sensitize gelatinous films [2]. Cationic (basic) dyes have been used 
for paper, polyacrylonitrile, modified polyesters, polyethylene terephthalate, and to some extent, in medicine, originally they were used for silk, wool, and tannin-mordanted cotton [3]. These water-soluble dyes yield coloured cations in solution and that is why they are called cationic dyes [4].

It is an excellent dye for staining procedure for nucleic acid in biology, and it is recommended for counterstaining of immune histochemically stained tissues to enhance nuclear staining without affecting the background [5]. The structure of methyl green is shown below;

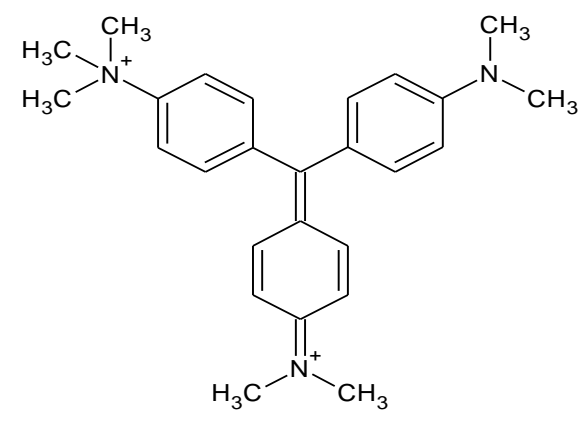

\section{Figure 1: Structure of Methyl Green [2].}

Because of potential toxicity of dyes and their visibility in surface waters, removal and degradation of organic dyes have been a matter of considerable interest [6]. Great concern has arisen about the thyroid peroxidase -catalyzed oxidation of the triphenylmethane class of dyes because the reactions might form various $\mathrm{N}$-de-alkylated primary and secondary aromatic amines, with structures similar to aromatic amine carcinogens.

\section{Cyanide}

Some drugs contain cyanide or substances which can be converted to cyanide within the body, example sodium nitroprusside $\left(\mathrm{Na}_{2} \mathrm{Fe}(\mathrm{CN})_{5} \mathrm{NO}\right)$ which is sometimes administered intravenously during the critical care treatment of hypertension, even though toxic

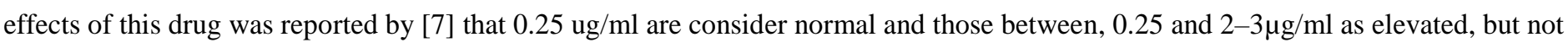
ordinarily causing death, while concentrations above $3 \mu \mathrm{g} / \mathrm{ml}$ are consistent with death in the absence of other relevant or toxicological findings [8].

\section{Experimental}

\section{Materials}

All chemicals and reagents used in this work were of analytical grade and were used without further purification. $\mathrm{MG}^{2+}$ and $\mathrm{CN}^{-}$were used as the oxidant and reductant respectively. Single distilled water was used throughout the experiment. $\mathrm{HClO}_{4}$ was used to investigate the effect of hydrogen ion on the rate of reduction. $\mathrm{NaClO}_{4}$ used as an inert electrolyte to maintain a constant ionic strength $(\mu)$ of the reaction medium. Methanol was used to change the dielectric constant of the reaction medium. $\mathrm{NH}_{4} \mathrm{Cl}_{2}, \mathrm{CaCl}_{2}$, $\mathrm{Na}_{2} \mathrm{NO}_{3}, \mathrm{CH}_{3} \mathrm{COOH}$ solution were used to investigate the effects of added ions on the rate of the reaction. 


\section{Method}

\section{Stoichiometric Studies}

The Stoichiometry study of the reaction was determined by spectrophotometric titration using the mole ratio method. The concentration of $\mathrm{MG}^{2+}$ was kept constant and the mole ratio of cyanide ion into $\mathrm{MG}^{2+}$ was varied in the concentration range $\left[\mathrm{CN}^{-}\right]=$ $(0.4-48) \times 10^{-5} \mathrm{~mol} \mathrm{dm}{ }^{-3}$, while keeping any other reaction condition constant at $\left[\mathrm{H}^{+}\right]$and ionic strength, at $2.0 \times 10^{-3} \mathrm{mold} / \mathrm{dm}^{3}$ and $0.196 \mathrm{~mol} / \mathrm{dm}^{3}$ respectively. The reaction was allowed to go to completion and the absorbance of the solutions monitored at $630 \mathrm{~nm}$, which is a characteristics of malachite green [9] the reaction was measured using UV Visible 721 spectrophotometer.

All kinetic measurements were carried out under pseudo-first order conditions with respective $\mathrm{CN}^{-}$concentrations with at least 100 folds excess of crystal violet concentration at temperature of $31 \pm 1^{0} \mathrm{C}$, ionic strength $0.196 \mathrm{~mol} / \mathrm{dm}^{3}\left(\mathrm{NaClO}_{4}\right)$, and $\left[\mathrm{H}^{+}\right]=2.0$ x $10^{-3}\left(\mathrm{HClO}_{4}\right)$.

The pseudo-first order plot of $\log \left(\mathrm{A}_{\mathrm{t}}-\mathrm{A}_{\infty}\right)$ against time were made and the slope of the plots gave pseudo-first order rate constants, $\mathrm{k}_{1}$, the second order rate constants, $\mathrm{k}_{2}$, were determined from $\mathrm{k}_{1}$ as $\frac{k_{1}}{[C N]}$.

Effect of changes in ionic strength on the reaction rates was studied by varying the ionic strength from $0.116-0.516 \mathrm{~mol} / \mathrm{dm}^{3}$ $\left(\mathrm{NaClO}_{4}\right)$ and maintaining $\left[\mathrm{MG}^{2+}\right],\left[\mathrm{CN}^{-}\right]$and $\left[\mathrm{H}^{+}\right]$constant at $4.0 \times 10^{-5} \mathrm{~mol} / \mathrm{dm}^{3}, 24.0 \times 10^{-3} \mathrm{~mol} / \mathrm{dm}^{3}$ and $2.0 \times 10^{-3} \mathrm{~mol} / \mathrm{dm}^{3}$ respectively. Reaction temperature was maintained at $31 \pm 1{ }^{\circ} \mathrm{C}$.

Effect of changes in dielectric constant of the reaction medium on the reaction rate was investigated by adding $0.10-0.8 \mathrm{~cm}^{3}$ (accounting for $2-16 \%$ ) methanol to the reaction mixture keeping $\left[\mathrm{MG}^{2+}\right],\left[\mathrm{CN}^{-}\right]$and $\left[\mathrm{H}^{+}\right]$constants. The ionic strength of 0.196 $\mathrm{mol} / \mathrm{dm}^{3}$ and temperature $31 \pm 1{ }^{0} \mathrm{C}$ were maintained. A plot of log $\mathrm{k}_{2}$ against $\frac{1}{D}$ gives the relationship between the second order rate constant and the total dielectric constant of the reaction medium D.

The effect of added ions on the reaction rate was observed by the addition of (2.0-12.0) x 10 $0^{-2} \mathrm{~mol} / \mathrm{dm}^{3}$ of ions $\left(\mathrm{NH}_{4}{ }^{+}, \mathrm{Ca}^{+}\right.$, $\left.\mathrm{NO}_{3}^{-}, \mathrm{CH}_{3} \mathrm{COO}^{-}\right)$keeping $\left[\mathrm{MG}^{2+}\right],\left[\mathrm{CN}^{-}\right]$and $\left[\mathrm{H}^{+}\right]$constant. The ionic strength of $0.196 \mathrm{Mol} / \mathrm{dm}^{3}$ and temperature of $31 \pm 1^{0} \mathrm{C}$ were maintained. Polymerization test was conducted by adding acrylamide solution to each of the partially oxidized reaction mixture containing various concentrations of oxidant, reductant and hydrogen ions, about $5 \mathrm{~cm}^{3}$ was added, followed by large excess of methanol. Any polymerization evidenced by gel formation would provide a suspicion for the presence of free radicals in the reaction mixture. Mickealis-Mensten plot $\frac{1}{k_{1}}$ versus $\frac{1}{C N^{-}}$also could give an idea on the presence or not of intermediate complex. 


\section{RESULT AND DISCUSSION.}

\section{STOICHIOMETRY}

Stoichiometry study revealed that one mole of the dye was consumed by two moles of the oxidant. Similar stoichiometry has been reported by Ahmad (2018) in the reaction of methyl green with $\mathrm{S}_{2} \mathrm{O}_{5}{ }^{2-}$

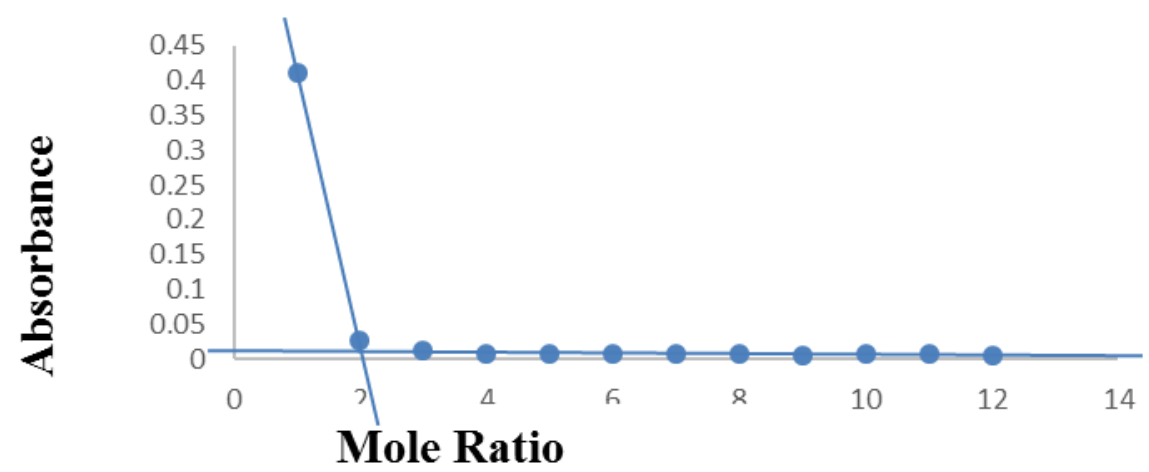

Figure 2: Plot of absorbance versus mole ratio for the determination of stoichiometry of the reduction of $\mathrm{MG}^{2+}$ by $\mathrm{CN}^{-}$at $\left[\mathrm{MG}^{2+}\right]=1.2$ $\times 10^{-5} \mathrm{~mol} \mathrm{dm}^{-3},\left[\mathrm{CN}^{-}\right]=24.0 \times 10^{-3} \mathrm{~mol} \mathrm{dm}^{-3},\left[\mathrm{H}^{+}\right]=2.0 \times 10^{-3} \mathrm{~mol} \mathrm{dm}^{-3}, \mu=0.196 \mathrm{~mol} \mathrm{dm}^{-3}\left(\mathrm{NaClO}_{4}\right), \mathrm{T}=31.0 \pm$ $1.0^{\circ} \mathrm{C}$ and $\lambda_{\max }=630 \mathrm{~nm}$.

\section{Order of Reaction}

The plot of $\log \left(\mathrm{A}_{t}-\mathrm{A}_{\infty}\right)$ versus time obtained under pseudo-first order conditions were linear for about $80 \%$ completion of the reaction. The linearity of these plots, suggested that the reaction is first order with respect to the oxidant $\left[\mathrm{MG}^{2+}\right]$, and a typical plot is represented in figure 3, which was 0.987 suggesting that the reaction is first order with respect to [CN']. The derived second order rate constants, $\mathrm{k}_{2}$ were fairly constant. The average value of the second order rate constants, $\mathrm{k}_{2}$ is $(4.0 \pm 0.06) \times 10^{-2} \mathrm{dm}^{3} / \mathrm{mol} / \mathrm{s}$. This means that the reaction is second order overall and the second order rate constant determined and are reported in table 1 . The rate law can therefore be represented by equation (1);

$$
-\frac{d\left[M G^{2+}\right]}{d t}=k_{2}\left[M G^{2+}\right]\left[C N^{-}\right]
$$

The order of one in both reactants in the reaction agrees with some reported order for the redox reaction of $\mathrm{MG}^{2+}$ versus $\mathrm{S}_{2} \mathrm{O}_{5}^{2-}, \mathrm{MG}^{2+}$ with $\mathrm{S}_{2} \mathrm{O}_{8}{ }^{2-}$ and $\mathrm{MG}^{2+}$ by $\mathrm{S}_{2} \mathrm{O}_{3}{ }^{2-}[1]$. 


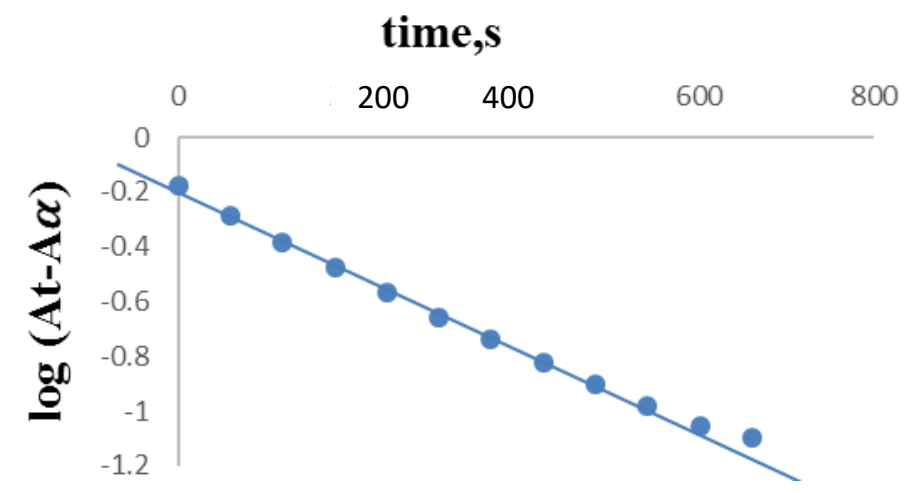

Figure 3: Pseudo-first order plot for the oxidation of $\mathrm{CN}^{-}$by $\mathrm{MG}^{2+}$ at $\left[\mathrm{MG}^{2+}\right]=1.2 \times 10^{-5} \mathrm{~mol} \mathrm{dm}^{-3}\left[\mathrm{CN}^{-}\right]=24.0 \times 10^{-3} \mathrm{~mol} \mathrm{dm}^{-3},\left[\mathrm{H}^{+}\right]$ $=2.0 \times 10^{-3}, \mu=0.196 \mathrm{~mol} \mathrm{dm}^{-3}\left(\mathrm{NaClO}_{4}\right), \mathrm{T}=31.0 \pm 1^{\circ} \mathrm{C}$ and $\lambda_{\max }=630 \mathrm{~nm}$

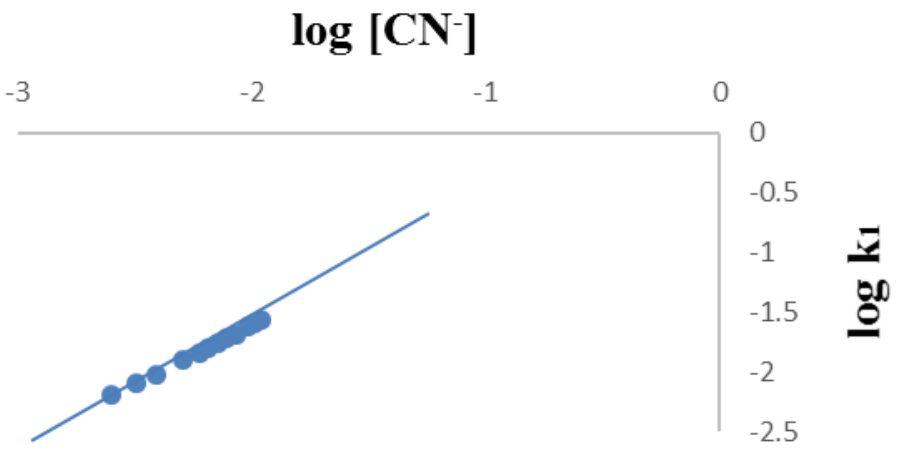

Figure 4: plot of $\log \mathrm{k}_{1}$ versus $\log \left[\mathrm{CN}^{-}\right]$for the reaction of $\mathrm{MG}^{2+} / \mathrm{CN}^{-}$at $\left[\mathrm{MG}^{2+}\right]=1.2 \times 10^{-5} \mathrm{~mol} / \mathrm{dm}^{3},\left[\mathrm{H}^{+}\right]=2.0 \times 10^{-3} \mathrm{~mol} / \mathrm{dm}^{3}, \mu=$ $0.196 \mathrm{~mol} / \mathrm{dm}^{3}, \mathrm{~T}=31 \pm 1^{0} \mathrm{C}$ and $\lambda_{\max }=630 \mathrm{~nm}$. 
Table 1: Pseudo-first order and second order rate constants for the reaction of $\mathrm{MG}^{2+}$ and $\mathrm{CN}^{-}$at $\left[\mathrm{MG}^{2+}\right]=1.2 \times 10^{-5} \mathrm{~mol} / \mathrm{dm}^{3},\left[\mathrm{H}^{+}\right]=$ $2.0 \times 10^{-3} \mathrm{~mol} / \mathrm{dm}^{3}, \mu=0.196 \mathrm{~mol} / \mathrm{dm}^{3}, \mathrm{~T}=31 \pm 1^{\circ} \mathrm{C}$ and $\lambda_{\max }=630 \mathrm{~nm}$

\begin{tabular}{|c|c|c|c|c|}
\hline $10^{3}\left[\mathrm{CN}^{-}\right] \mathrm{mol} / \mathrm{dm}^{3}$ & $10^{4}\left[\mathrm{H}^{+}\right] \mathrm{mol} / \mathrm{dm}^{3}$ & $10[\mu] \mathrm{mol} / \mathrm{dm}^{3}$ & $10^{3} \mathrm{k}_{1}, \mathrm{~s}^{-1}$ & $10 \mathrm{k}_{2} \mathrm{~mol} / \mathrm{dm}^{3} \mathrm{~s}^{-1}$ \\
\hline 6.4 & 4.0 & 1.96 & 2.53 & 3.95 \\
\hline 8.0 & 4.0 & 1.96 & 3.22 & 4.02 \\
\hline 9.6 & 4.0 & 1.96 & 3.91 & 4.07 \\
\hline 12.8 & 4.0 & 1.96 & 5.07 & 3.96 \\
\hline 14.4 & 4.0 & 1.96 & 5.99 & 4.15 \\
\hline 16.0 & 4.0 & 1.96 & 6.45 & 4.03 \\
\hline 17.6 & 4.0 & 1.96 & 7.14 & 4.05 \\
\hline 19.2 & 4.0 & 1.96 & 7.83 & 4.07 \\
\hline 20.8 & 4.0 & 1.96 & 8.52 & 4.09 \\
\hline 24.0 & 4.0 & 1.96 & 9.67 & 4.02 \\
\hline 25.6 & 4.0 & 1.96 & 10.36 & 4.04 \\
\hline 27.2 & 4.0 & 1.96 & 11.05 & 4.06 \\
\hline 24.0 & 1.6 & 1.96 & 9.67 & 4.02 \\
\hline 24.0 & 2.4 & 1.96 & 9.67 & 4.02 \\
\hline 24.0 & 3.2 & 1.96 & 9.67 & 4.02 \\
\hline 24.0 & 4.0 & 1.96 & 9.67 & 4.02 \\
\hline 24.0 & 4.8 & 1.96 & 9.67 & 4.02 \\
\hline 24.0 & 5.6 & 1.96 & 9.67 & 4.02 \\
\hline 24.0 & 6.4 & 1.96 & 9.67 & 4.02 \\
\hline 24.0 & 7.2 & 1.96 & 9.67 & 4.02 \\
\hline 24.0 & 8.0 & 1.96 & 9.67 & 4.02 \\
\hline 24.0 & 8.8 & 1.96 & 9.67 & 4.02 \\
\hline 24.0 & 9.6 & 1.96 & 9.67 & 4.02 \\
\hline 24.0 & 10.4 & 1.96 & 9.67 & 4.02 \\
\hline 24.0 & 4.0 & 1.16 & 12.8 & 5.33 \\
\hline 24.0 & 4.0 & 1.56 & 11.0 & 4.58 \\
\hline 24.0 & 4.0 & 1.96 & 9.67 & 4.02 \\
\hline 24.0 & 4.0 & 2.36 & 9.21 & 3.83 \\
\hline 24.0 & 4.0 & 2.76 & 8.29 & 3.45 \\
\hline 24.0 & 4.0 & 3.16 & 7.59 & 3.16 \\
\hline 24.0 & 4.0 & 3.56 & 7.36 & 3.06 \\
\hline 24.0 & 4.0 & 3.96 & 6.90 & 2.87 \\
\hline 24.0 & 4.0 & 4.36 & 6.44 & 2.68 \\
\hline
\end{tabular}

\section{Effect of Hydrogen ion Concentration}

The effect of $\left[\mathrm{H}^{+}\right]$on the rate of reaction is reported in table 1 . The $\mathrm{k}_{2}$ values obtained from changes in hydrogen ion concentration indicated the reaction rate is not affected by these changes. This suggests that none of the reactants is significantly protonoted under the reaction condition [10]. The order with respect to $\left[\mathrm{H}^{+}\right]$was found to be zero from the plot of $\log \left[\mathrm{H}^{+}\right]$versus $\log$ $\mathrm{k}_{1}$. 


\section{Effect of Changes in Ionic Strength}

The rate of reaction was found to decrease with increase in ionic strength. The results are presented on table 1 . The observed negative Bronsted-Debye salt effect suggests that the activated complex is composed of oppositely charged species [11]. Plot of $V_{\mu}$ versus log $\mathrm{k}_{1}$ was linear and represented in figure 5 .

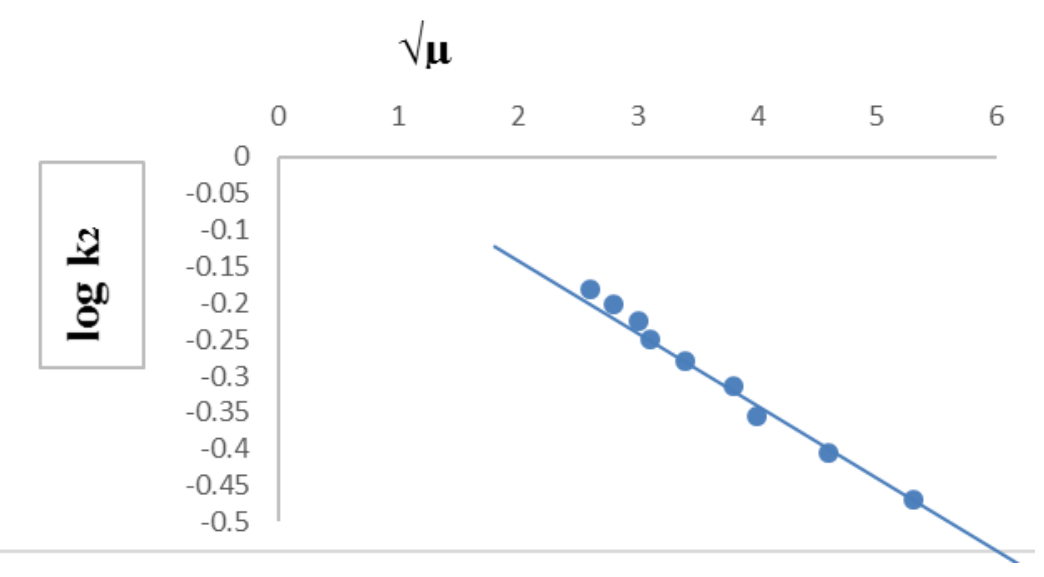

Figure 5: Plot of $\log \mathrm{k}_{2}$ against $\sqrt{\mu}$ for the reduction of $\mathrm{MG}^{2+}$ by $\mathrm{CN}^{-}$at $\left[\mathrm{MG}^{2+}\right]=1.2 \times 10^{-5} \mathrm{~mol} \mathrm{dm}^{-3},\left[\mathrm{CN}^{-}\right]=24.0 \times 10^{-3} \mathrm{~mol} \mathrm{dm}^{-3}$, $\left[\mathrm{H}^{+}\right]=2.0 \times 10^{-3} \mathrm{~mol} \mathrm{dm}^{-3}, \mu=0.116-0.296 \mathrm{~mol} \mathrm{dm}^{-3}\left(\mathrm{NaClO}_{4}\right), \mathrm{T}=31.0 \pm 1.0^{\circ} \mathrm{C}$ and $\lambda_{\max }=630 \mathrm{~nm}$

\section{Effect of Total Dielectric Constant}

Table 2 shows the result for total dielectric constant (D), increased in concentration of D lead to an increase in the rate constant. The result suggests that outer-sphere mechanism is probably in operation, suggesting that the reactant ions in the rate determining step are oppositely charged [12]. Plot of $\frac{1}{D}$ against $\log \mathrm{k}_{1}$ was linear and was represented in figure 6 .

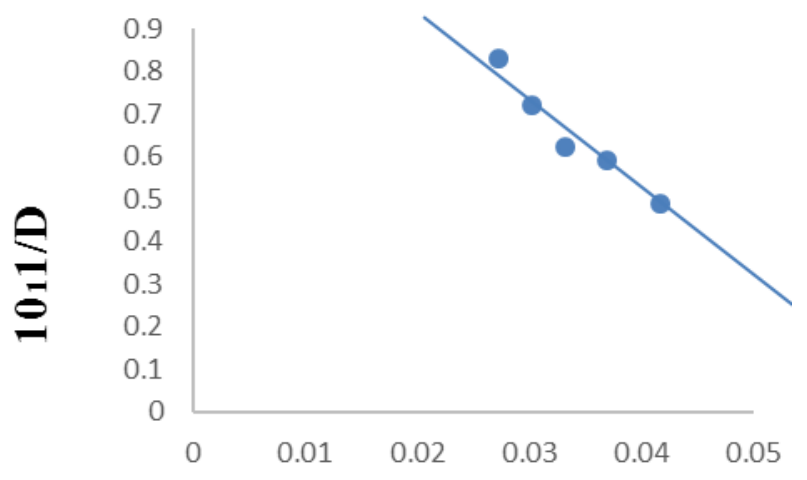

\section{$\log \mathbf{k} 2$}

Figure 6: Plot of $\log \mathrm{k}_{2}$ against 1/D for the reduction of $\mathrm{MG}^{2+}$ by $\mathrm{CN}^{-}$at $\left[\mathrm{MG}^{2+}\right]=1.2 \times 10^{-5} \mathrm{~mol} \mathrm{dm}^{-3},\left[\mathrm{CN}^{-}\right]=24.0 \times 10^{-3} \mathrm{~mol} \mathrm{dm}^{-3}$, $\left[\mathrm{H}^{+}\right]=2.0 \times 10^{-3} \mathrm{~mol} \mathrm{dm}^{-3}, \mu=0.196 \mathrm{~mol} \mathrm{dm}^{-3}\left(\mathrm{NaClO}_{4}\right), \mathrm{T}=31.0 \pm 1.0^{\circ} \mathrm{C}$ and $\lambda_{\max }=630 \mathrm{~nm}$ 
Table 2. Effect of Changes in Total Dielectric Constant of the Reaction Medium on the Reaction of Methyl Green and Cyanide Ion at $\left[\mathrm{MG}^{2+}\right]=1.2 \times 10^{-5} \mathrm{~mol} / \mathrm{dm}^{3},\left[\mathrm{CN}^{-}\right]=24.0 \times 10^{-3},\left[\mathrm{H}^{+}\right]=2.0 \times 10^{-3} \mathrm{~mol} / \mathrm{dm}^{3}, \mu=0.196 \mathrm{~mol} / \mathrm{dm}^{3}, \mathrm{~T}=31 \pm 1^{\circ} \mathrm{C}$ and $\lambda_{\max }=630$ nm.

\begin{tabular}{llll}
\hline $\mathrm{D}$ & $10^{2 \frac{1}{D}}$ & $10^{3} \mathrm{k}_{1} \mathrm{~s}$ & $10^{1} \mathrm{k}_{2} \mathrm{dm}^{3} / \mathrm{mol}^{\prime} / \mathrm{s}$ \\
\hline 0.00 & 0 & 9.67 & 4.0 \\
24.03 & 4.1615 & 11.75 & 4.9 \\
27.05 & 3.6968 & 14.05 & 5.9 \\
30.08 & 3.3244 & 14.97 & 6.2 \\
33.10 & 3.0211 & 17.27 & 7.2 \\
36.21 & 2.7616 & 20.04 & 8.3
\end{tabular}

\section{Effect of Added Ions on the Rate of the Reaction}

Added $\mathrm{NH}_{4}^{+}$and $\mathrm{Ca}^{2+}$ lead to decrease in reaction rate while increase in the concentrations of $\mathrm{NO}_{3}{ }^{-}$and $\mathrm{CH}_{3} \mathrm{COO}^{-}$have no remarkable effect on the reaction rate (Table 3) and a typical plot is represented in figure 7 . This inhibitory effect of added cation could be explain in terms of Columbic effects, at the activated complex in this reaction is made up of positive charge species, bringing in another positively charge species would lead to overall repulsion, thereby decreasing the rate of the reaction. The effect of these ions however suggests that outer-sphere mechanism might be operating in the system [13

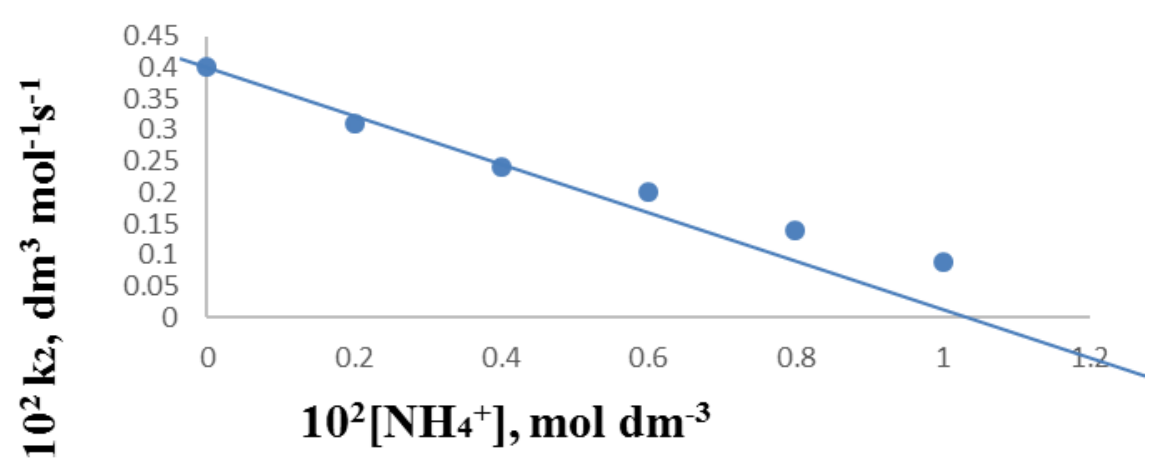

Figure 7: Plot of dependence of $\mathrm{k}_{2}$ on $\left[\mathrm{NH}_{4}^{+}\right]$for the reaction of $\mathrm{MG}^{2+}$ with $\mathrm{CN}^{-}$at $\left[\mathrm{MG}^{2+}\right]=1.2 \times 10^{-5} \mathrm{~mol} \mathrm{dm}^{-3},\left[\mathrm{CN}^{-}\right]=24.0 \times 10^{-3}$ $\mathrm{mol} \mathrm{dm}{ }^{-3},\left[\mathrm{H}^{+}\right]=2.0 \times 10^{-3} \mathrm{~mol} \mathrm{dm}^{-3}, \mu=0.196 \mathrm{~mol} \mathrm{dm}^{-3}\left(\mathrm{NaClO}_{4}\right), \lambda_{\max }=630 \mathrm{~nm}$ and $\mathrm{T}=31.0 \pm 1.0^{\circ} \mathrm{C}$ 


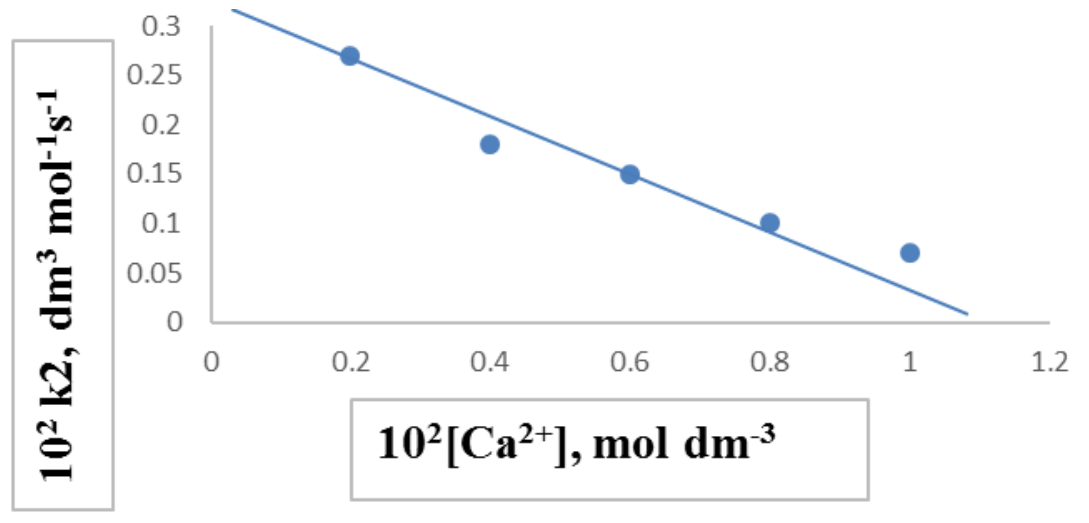

Figure 8: Plot of dependence of $\mathrm{k}_{2}$ on $\left[\mathrm{Ca}^{2+}\right]$ for the reaction of $\mathrm{MG}^{2+}$ with $\mathrm{CN}^{-}$at $\left[\mathrm{MG}^{2+}\right]=1.2 \times 10^{-5} \mathrm{~mol} \mathrm{dm}^{-3},\left[\mathrm{CN}^{-}\right]=24.0 \times 10^{-3}$ $\mathrm{mol} \mathrm{dm}{ }^{-3},\left[\mathrm{H}^{+}\right]=2.0 \times 10^{-3} \mathrm{~mol} \mathrm{dm}{ }^{-3}, \mu=0.196 \mathrm{~mol} \mathrm{dm}^{-3}\left(\mathrm{NaClO}_{4}\right), \lambda_{\max }=630 \mathrm{~nm}$ and $\mathrm{T}=31.0 \pm 1.0^{\circ} \mathrm{C}$.

Table 3. Effect of Added Cations to the reaction medium on the rate constants for the oxidation of Methyl Green by Cyanide ion at $\left[\mathrm{MG}^{2+}\right]=1.2 \times 10^{-5} \mathrm{~mol} / \mathrm{dm}^{3}, \mu=0.196 \mathrm{~mol} / \mathrm{dm}^{3,} \mathrm{~T}=31 \pm 1^{0} \mathrm{C},\left[\mathrm{H}^{+}\right]=2.0 \times 10^{-3} \mathrm{~mol} / \mathrm{dm}^{3}, \lambda_{\max }=630 \mathrm{~nm},[\mathrm{CN}]=24.0 \times 10^{-}$ ${ }^{3} \mathrm{~mol} / \mathrm{dm}^{3}$.

\begin{tabular}{cccc}
\hline Ions & $10^{2}[\mathrm{X}] \mathrm{mol} / \mathrm{dm} 3$ & $10^{3} \mathrm{k}_{1} \mathrm{~s}$ & $10 \mathrm{k}_{2} \mathrm{dm}^{3} / \mathrm{mol}^{\mathrm{s}}$ \\
\hline $\mathrm{NH}_{4}{ }^{+}$ & 0.00 & 9.67 & 4.02 \\
& 20.0 & 7.37 & 3.07 \\
40.0 & 5.76 & 2.40 \\
60.0 & 4.84 & 2.01 \\
& 80.0 & 3.45 & 1.43 \\
& 100 & 2.07 & 0.86 \\
& 0.00 & 9.67 & 4.02 \\
$\mathrm{Ca}^{2+}$ & 20.0 & 6.45 & 2.68 \\
& 40.0 & 4.38 & 1.82 \\
& 60.0 & 3.68 & 1.53 \\
& 80.0 & 2.30 & 0.09 \\
& 100 & 1.61 & 0.06
\end{tabular}

\section{Effect of Temperature on the Reaction Rate}

Increase in temperature resulted to an increase in the observed rate constants $\left(\mathrm{K}_{\mathrm{obs}}\right)$. Hence, from the plot of Arrhenius plot of InK $\mathrm{obs}_{\text {versus }} \frac{1}{T}$. The entropy of activation $\left(\Delta \mathrm{S}^{*}\right)$, enthalpy of activation, $\left(\Delta \mathrm{H}^{*}\right)$ and Gibbs free energy of activation $\left(\Delta \mathrm{G}^{*}\right)$ were obtained from erying's equation as $-0.1726 \mathrm{KJ} / \mathrm{K} / \mathrm{mol}, 24.942 \mathrm{KJ} / \mathrm{mol}$ and $77.2398 \mathrm{KJ} / \mathrm{mol}$ respectively. The result showed that an associative mechanism is operating and an endothermic reaction due the influence of some external forces. 
$\log \mathrm{K}=\log \mathrm{A}-\frac{E a}{2.304 R T}$

$$
\begin{aligned}
& \text { In }\left(\frac{K}{T}\right)=\frac{-\Delta H+}{R 7}+\operatorname{in}\left(\frac{k 1}{h}\right)+\left(\frac{\Delta S *}{R}\right) \\
& \operatorname{In}\left(\frac{K 1}{H}\right)=23.76 \\
& \Delta \mathrm{G}^{*}=\Delta \mathrm{H}^{*}-\mathrm{T} \Delta \mathrm{S}^{*}
\end{aligned}
$$

$\mathrm{K}=$ Observed rate constant

$\mathrm{T}=$ temperature

$\Delta \mathrm{H}^{*}=$ enthalpy of activation

$\Delta \mathrm{S}^{*}=$ entropy of activation

$\Delta G^{*}=$ Gibb's free energy of activation

$\mathrm{R}=$ molar gas constant

$\mathrm{K}^{1}=$ Boltzmann's constant

$\mathrm{H}=$ plank’s constant.

\section{TEST FOR INTERMEDIATE COMPLEX FUNCTION}

Michaeli's-menten plot of $\frac{1}{K_{o b s}}$ versus $\frac{1}{C N^{-}}$gave a straight line passing through the origin that is zero intercept (figure 9), suggesting the absence of intermediate complex. Also spectrum of the reaction mixture taken 2 minutes after the initiation of the reaction showed no shift from the $\lambda_{\max }$ of $630 \mathrm{~nm}$ characteristics of Methyl Green.

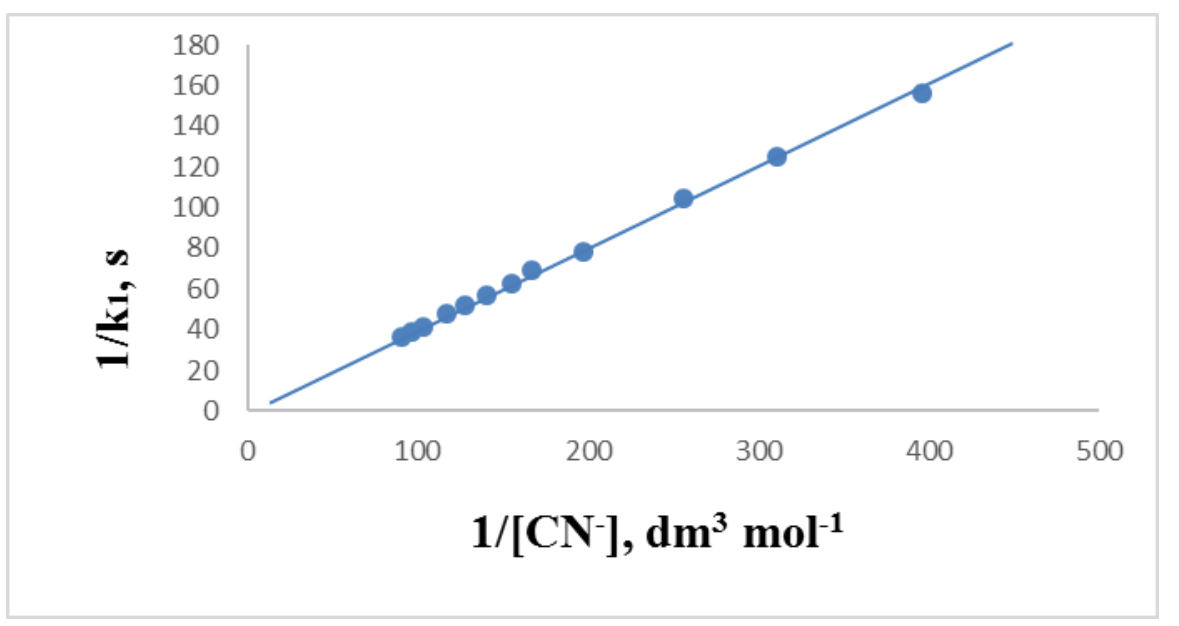

Figure 9: Michaelis-Menten plot of $1 / \mathrm{k}_{1}$ versus $1 /\left[\mathrm{CN}^{-}\right]$for the reduction of $\mathrm{MG}^{2+}$ by $\mathrm{CN}^{-}$at $\left[\mathrm{MG}^{2+}\right]=1.2 \times 10^{-5} \mathrm{~mol} \mathrm{dm}^{-3},\left[\mathrm{H}^{+}\right]=$ $2.0 \times 10^{-3} \mathrm{~mol} \mathrm{dm}^{-3}, \mu=0.196 \mathrm{~mol} \mathrm{dm}^{-3}\left(\mathrm{NaClO}_{4}\right), \mathrm{T}=31.0 \pm 1.0^{\circ} \mathrm{C}$ and $\lambda_{\max }=630 \mathrm{~nm}$ 


\section{Test for participation of free radicals}

Addition of acrylamide to the partially oxidized mixture in excess methanol did not form a gel, nor suspension and no cloud, suggesting absence of free radicals in the cause of the reaction.

\section{MECHANISMS OF REACTION}

Based on the results obtained, the following mechanism is proposed

$\begin{array}{llll}\mathrm{MG}^{2+}+\mathrm{CN}^{-} \stackrel{\mathrm{k}_{1}}{\rightarrow} \quad\left[\mathrm{MG}^{2+} / / \mathrm{CN}^{-}\right] & \ldots 3 \\ {\left[\mathrm{MG}^{2+} / / \mathrm{CN}^{-}\right] \quad \mathrm{k}_{2} \rightarrow \text { Product }} & \ldots 4 \\ \text { Rate }=\mathrm{k}_{2}\left[\mathrm{MG}^{2+} / / \mathrm{CN}^{-}\right] & \ldots 5\end{array}$

From equation 3

$\mathrm{MG}^{2+}+\mathrm{CN}^{-} \stackrel{\mathrm{k}_{1}}{\rightarrow} \mathrm{k}_{1}\left[\mathrm{MG}^{2+} / / \mathrm{CN}^{-}\right]$

Substituting (6) into (5)

Rate $=\mathrm{k}_{2} \mathrm{k}_{1}\left[\mathrm{MG}^{2+}\right]\left[\mathrm{CN}^{-}\right]$

The proposed outer-sphere mechanism pathway was as due to the following reason:

i. The rate of the reaction was inhibited in the presence of added cations, this is characteristic of reactions occurring via the outersphere mechanism.

ii. Spectroscopic evidence indicated no shift in $\lambda_{\max }$ suggesting that there was absence of detectable intermediate species during the course of the reaction. This observation also suggested the outer-sphere mechanism.

iii. Michaelis - Menten plot of $1 / \mathrm{k}_{1}$ versus $1 /\left[\mathrm{CN}^{-}\right]$had zero intercept which suggests the absence of a detectable intermediate in the rate determining step. This observation suggests the occurrence of the outer-sphere mechanism.

From the above points $\mathbf{i}-\mathbf{i i i}$, it is evident that the reaction is operating through the outer-sphere mechanism and is hereby proposed for the reaction.

\section{Conclusion}

The kinetic investigation of the redox reaction between $\mathrm{MG}^{2+}$ and cyanide ion $\left(\mathrm{CN}^{-}\right)$were carried out in aqueous $\mathrm{HClO}_{4}$ medium at $\mathrm{T}=31 \pm 1^{\circ} \mathrm{C}$. The reaction showed stoichiometry of $1: 2$. The kinetic data revealed a first order dependence on both $\left[\mathrm{MG}^{2+}\right]$ and $\left[\mathrm{CN}^{-}\right]$given a second order overall. Reaction rate followed acid independent pathway within the range investigated and was inhibited by increase in an ionic strength medium, but increased mildly with increase in total dielectric constant of reaction medium 
and inhibited by added ions. Spectrophotometric test showed absence of intermediate complex formation. This suggestion is confirmed by the evidence adduced from the Mickaeli's-mentens plot.

Based on the above results, it is evident that the reaction is probably operating through the outer-sphere mechanism 


\section{References}

[1]. Ahmad, B. G. (2018). Kinetic Study of the Decolorization of Methyl Green by some Oxyanions under Acidic Medium. Unpublished M.Sc. Thesis, University of Maiduguri, Borno, Nigeria. 2-16.

[2]. Mai, F. D., Chem, C. C., Chem, J. C. and Liu, S. C. (2008). Photodegradation of Methyl Green Using Visible Irradiation in ZnO Suspentions. Journal of Chromatograph. 1189 (1-2): 355 - 365.

[3]. Nezamzadeh-Ejhieh, A. and Shams-Ghahfarokhi, Z. (2013). "Photodegredation of Methyl Green by NickelDimethylglyoxime/ZSM-5Zeolite as a Hetrogeneous Catalyst", Hindawi Publishing Corporation Journal of Chemistry. Article ID104093.11.

[4]. Gupta, V. K. and Suhas, G. (2009). "Application of Low-Cost Adsorbents for Dye Removal. A Review. Journal of Environmental Management.90(8) 2313-2342.

[5]. Rainbow, R. D. (1994). Immunoflourescence in laboratory Pathology. New York: Cherchill Living Stone.

[6]. Habibi, M. H. and Askari, E. (2011). "Photocatalytic Degradation of an Azo Textile Dye with Manganese-doped ZnO Nano Particles Coated on Glass.”Iranian Journal of Catalysis. 1 41-44.

[7]. Sani, M., Sebal, H., Boughattas, N. and Ben, A. M. (2011). Time of Day Dependence of Neurological Deficits Induced by Sodium Nitropruside in Young Mice. Journal of Circadian Rhythms. 9, 1-8.

[8]. Gamboro, V., Arnold S., Casagni, E., Dell Acqua, L., Pecoraro ch. and Faldi R. (2007). Blood Cyanide Determination in Two Cases of Fatal Intoxication: Comparison between Headspace Gas Chromatography and a Spectrophotometric Method. Journal of Forensic Science. 52, 1401-1404.

[9]. Mohammed, Y. (2015). Kinetics and mechanisms of the electron transfer reactions of diaquo tetrakis (2,2'-BIPYRIDINE)- $\mu$ oxodiruthenium(III)ions and some reductants in aqueous medium. Ph. D. Thesis, Department of Chemistry, Ahmadu Bello University, Zaria. Nigeria. 30-33.

[10]. Mohammed,Y., Etonihu, A.C. and Tsaku, V.A. (2011). Kinetics and Mechanism of Hexamethyl Pararosaniline Chloride (Crytal Violet) by Chlorate Ions in Aqueous Acidic Media. Trakia Journal of Science. 9(2): 1-7.

[11]. Wilkins, G.R. (1974). The Study of Kinetics and Mechanisms of Cobalt(III)- EDTA Type Complexes. Allyn and Bacon, Inc. Boston. 231-239.

[12]. Idris, S. O., Tanimu, A., Iyun, J. F. and Mohammed, Y. (2015). Kinetics and Mechanism of Malachite Green Oxidation by Hypochlorite Ion in Aqueous Acidic Medium. American Chemical Science Journal. 5(2): 185-193. ISSN: $2249-0205$.

[13]. Babatunde, O.A. (2005) Kinetics and mechanism of electron transfer reactions of mixed-valence di- $\mu$-oxo tetrakis (1,10phenanthroline) di manganese (iii,iv) ion and rosaniline hydrochloride with some reducing agents. An unpublished Ph.D Thesis of Ahmadu Bello University, Zaria, Nigeria. 